Article

\title{
In Situ Determination of Bisphenol A in Beverage Using a Molybdenum Selenide/Reduced Graphene Oxide Nanoparticle Composite Modified Glassy Carbon Electrode
}

\author{
Rongguang Shi ${ }^{1}$, Jing Liang ${ }^{2}$, Zongshan Zhao ${ }^{2, *}$, Yi Liu $^{3, *(\mathbb{D}}$ and Aifeng Liu ${ }^{2}$ \\ 1 Key Laboratory for Environmental Factors Control of Agro-Product Quality Safety, Agro-Environmental \\ Protection Institute, Ministry of Agriculture, Tianjin 300191, China; shirongguang@aepi.org.cn \\ 2 CAS Key Laboratory of Biobased Materials, Qingdao Institute of Bioenergy and Bioprocess Technology, \\ Chinese Academy of Sciences, Qingdao 266101, China; liangjing@qibebt.ac.cn (J.L.); \\ Liuaf@qibebt.ac.cn (A.L.) \\ 3 School of Chemistry and Chemical Engineering, Yantai University, Yantai 264005, China \\ * $\quad$ Correspondence: zhaozs@qibebt.ac.cn (Z.Z.); liuyi@ytu.edu.cn (Y.L.); Tel.: +86-532-80662709 (Z.Z.)
}

Received: 3 April 2018; Accepted: 11 May 2018; Published: 22 May 2018

check for updates

\begin{abstract}
Due to the endocrine disturbing effects of bisphenol A (BPA) on organisms, rapid detection has become one of the most important techniques for monitoring its levels in the aqueous solutions associated with plastics and human beings. In this paper, a glassy carbon electrode (GCE) modified with molybdenum selenide/reduced graphene oxide $\left(\mathrm{MoSe}_{2} / \mathrm{rGO}\right)$ was fabricated for in situ determination of bisphenol A in several beverages. The surface area of the electrode dramatically increases due to the existence of ultra-thin nanosheets in a flower-like structure of $\mathrm{MoSe}_{2}$. Adding phosphotungstic acid in the electrolyte can significantly enhance the repeatability (RSD $=0.4 \%$ ) and reproducibility $(\mathrm{RSD}=2.2 \%)$ of the electrode. Under the optimized condition $(\mathrm{pH}=6.5)$, the linear range of BPA was from $0.1 \mu \mathrm{M}-100 \mu \mathrm{M}$ and the detection limit was $0.015 \mu \mathrm{M}(\mathrm{S} / N=3)$. When using the as-prepared electrode for analyzing BPA in beverage samples without any pretreatments, the recoveries ranged from $98-107 \%$, and the concentrations were from below the detection limit to $1.7 \mu \mathrm{M}$, indicating its potential prospect for routine analysis of BPA.
\end{abstract}

Keywords: electrochemical sensor; molybdenum selenide; reduced graphene oxide; bisphenol A; beverage

\section{Introduction}

Bisphenol A (BPA), an endocrine-disrupting chemical (EDC) [1], has been of great concern as a result of its adverse physiological effects and frequent detections in various environmental mediums [2-4]. Since BPA has been widely used for the production of cups and packing materials [5-7], its migration from storage or packaging material to food or beverage [8] has been proposed as one of the important exposure pathways for human beings. The European Food Safety Authority (EFSA) has established a temporary Tolerable Daily Intake (t-TDI) of $4 \mu \mathrm{g} / \mathrm{kg}$ b.w./day for BPA [9]. Therefore, BPA usage in some infant food packages and bottles has been banned by legislation [10].

To monitor the environmental levels, behaviors and fate of BPA, many methods, such as capillary electrophoresis [11], gas chromatography coupled with mass spectrometry (GC-MS) [12], high performance liquid chromatography mass spectrometry (HPLC-MS) [13], enzyme linked immune sorbent assay (ELISA) [14], electrochemical methods [15,16], etc., have been developed. Combined with pretreatment procedures of solid-phase extraction [17], liquid-liquid extraction [18] and immunoaffinity 
chromatography [19], GC-MS, HPLC-MS and ELISA can be used for selectively and sensitively determining BPA in complex matrices [20,21]. However, the complementary pretreatments and expensive equipment have restricted their application.

Electrochemical methods are some of the preferable techniques for routine analysis of some chemical compounds owing to the inherent advantages of the low cost of the instrument, ease of preparation, high sensitivity, simplicity for operators and in situ monitoring [22]. To improve the response signals of substances, a series of modified electrodes has been developed. For example, electrodes based on graphene nanomaterials present excellent electric conductivity, as well as chemical and thermal stability $[23,24]$. Electrodes modified with molybdenum-selenide $\left(\mathrm{MoSe}_{2}\right)$ show very good sensitivity as a result of increasing the surface active sites $[25,26]$.

$\mathrm{MoSe}_{2}$ /graphene composites are proposed as useful materials for fabricating electrochemical sensors and biosensors due to their excellent physical and chemical properties of large surface and better conductivity [27]. In this paper, a novel electrochemical sensor based on molybdenum selenide/reduced graphene oxide ( $\mathrm{MoSe}_{2} / \mathrm{rGO}$ ) nanocomposites has been developed for in situ determination of BPA in beverages. The performance of the electrode has been evaluated by analyzing BPA in some commercial beverages without any pretreatments or purification.

\section{Experimental}

\subsection{Reagents and Materials}

BPA, phosphotungstic acid $\left(\mathrm{H}_{3}\left[\mathrm{PW}_{12} \mathrm{O}_{4}\right]\right.$, PTA), graphite powders, Se powder, sodium molybdate, sodium hydroxide $(\mathrm{NaOH})$, potassium permanganate $\left(\mathrm{KMnO}_{4}\right)$, sulfuric acid $\left(\mathrm{H}_{2} \mathrm{SO}_{4}, 98 \%\right)$, sodium nitrate $\left(\mathrm{NaNO}_{3}\right)$ and phosphoric acid $\left(\mathrm{H}_{3} \mathrm{PO}_{4}\right)$ were purchased from Sinopharm Group Chemical Regent Co. Ltd. (Shanghai, China). BPA was dissolved in ethanol and kept at $4{ }^{\circ} \mathrm{C}$. PTA $(1 \mathrm{mM})$ and phosphate buffer solution (PBS, $1 \mathrm{M}, \mathrm{pH}=6.5$ ) were used as reduced and supporting electrolytes. All chemicals used were at least analytical grade. Ultrapure water $(18.2 \mathrm{M} \Omega \cdot \mathrm{cm}$, obtained by Milli-Q Water Purification System, Billerica, MA, USA) was used for preparing all buffers and standard solutions.

\subsection{Instruments}

All cyclic voltammetry (CV) measurements were performed using a CHI660E electrochemical workstation (Chenhua Instruments, Shanghai, China) with a conventional three-electrode system. A glassy carbon electrode (GCE) was used as the working electrode, with an $\mathrm{Ag} / \mathrm{AgCl}$ electrode and a platinum wire electrode as the reference electrode and counter-electrode, respectively. Measurements of $\mathrm{pH}$ were carried out by a Mettler Toledo Delta $320 \mathrm{pH}$ meter (Shanghai, China). The morphologies of materials and electrodes were obtained using transmission electron microscopy (TEM) (Hitachi H-7650, Hitachi High-Technologies Corporation, Japan). The X-ray diffraction (XRD) of the samples was carried out using Bruker XRD (Bruker D8 advance Diffracto meter, Bruker Germany).

\subsection{Preparation of $\mathrm{MoSe}_{2} / \mathrm{rGO}$ Composite}

The $\mathrm{MoSe}_{2}$ nanoparticles (NPs) were synthesized by the hydrothermal method [28]. Briefly, Se solution ( $5 \mathrm{~mL}, 0.4 \mathrm{M}$ in hydrazine hydrate) was added dropwise to sodium molybdate solution $(50 \mathrm{~mL}, 0.02 \mathrm{M})$. The mixture was transferred into a $100 \mathrm{~mL}$ Teflon-lined autoclave and heated at $180{ }^{\circ} \mathrm{C}$ for $48 \mathrm{~h}$. The black $\mathrm{MoSe}_{2}$ nanoparticles were obtained after washing with distilled water and drying in a vacuum. The graphite oxide (GO) was prepared according to previous reports [29].

The preparation of the $\mathrm{MoSe}_{2} / \mathrm{rGO}$ was completed as below. The synthesized $\mathrm{MoSe}_{2}$ nanoparticles $(0.5 \mathrm{~mL}, 1 \mathrm{mg} / \mathrm{mL}$ in water) were mixed with $\mathrm{GO}(10 \mathrm{~mL}, 1 \mathrm{mg} / \mathrm{mL}$ in water) and stirred for $2 \mathrm{~h}$. $\mathrm{MoSe}_{2} / \mathrm{GO}(5 \mu \mathrm{L})$ was cast onto the pre-polished and cleaned GCE surface and dried naturally. Then, $\mathrm{MoSe}_{2} / \mathrm{rGO}$ nanoparticle films were prepared on the GCE surface by the electrochemical reduction process. The electrolytes were phosphate buffer solutions. The reduced potential was $-1.2 \mathrm{~V}$, and the 
time was $120 \mathrm{~s}$, respectively. A similar procedure was also used to fabricate modified electrodes of $\mathrm{MoSe}_{2} \mathrm{NPs} / \mathrm{GCE}$ and rGO/GCE.

\subsection{Analysis of Real Sample}

Coffee, soybean milk powder, prepared juice, liquid milk and orange juice samples obtained from a local supermarket were used for evaluating the performance of the prepared electrode. Liquid samples of liquid milk and orange juice were directly mixed with PBS solution for analysis without any pretreatment. For coffee, soybean milk powder and prepared juice, certain amounts $(2.5 \mathrm{~g})$ of these solid samples were firstly mixed with $25 \mathrm{~mL}$ ultrapure water in plastic bottle and then heated to $100{ }^{\circ} \mathrm{C}$ for $1 \mathrm{~h}$. Finally, the obtained solutions were cooled to room temperature $\left(25^{\circ} \mathrm{C}\right)$ for further analysis after spiking with BPA standard solutions.

\section{Results and Discussion}

\subsection{Characterization of Electrode Materials}

The TEM images showed that $\mathrm{MoSe}_{2}$ nanoparticles possess flower-like structures being composed of ultra-thin nanosheets, and their diameters were about $200 \mathrm{~nm}$ (Figure 1A). In the $\mathrm{MoSe}_{2} / \mathrm{GO}$ composites, it was obvious that the layered $\mathrm{MoSe}_{2}$ nanosheets have been well wrapped in the thin graphene film (Figure 1B). The characteristic diffraction peaks were indexed to (002), (100) and (110) planes from the XRD pattern of $\mathrm{MoSe}_{2} / \mathrm{rGO}$ composites corresponding to that of $\mathrm{rGO}$ and monoclinic $\mathrm{MoSe}_{2}$ nanoparticles (JCPDS: 77-1715), indicating the successful combination of $\mathrm{MoSe}_{2}$ and rGO.
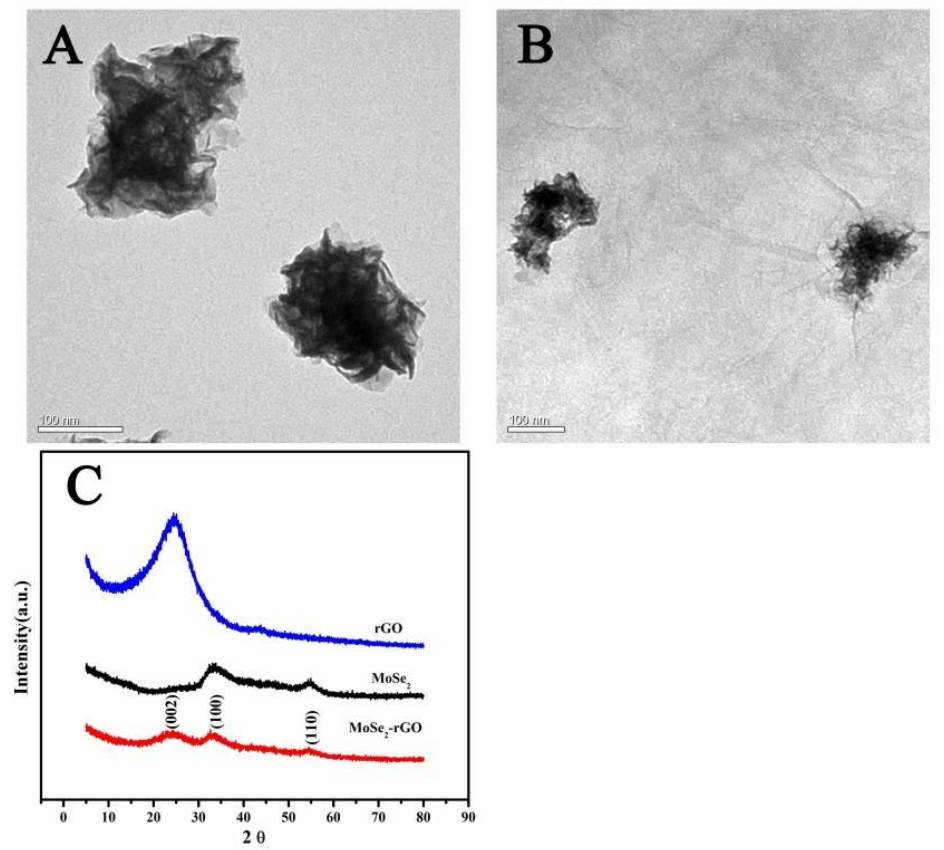

Figure 1. Characterization of the prepared electrode materials. (A) TEM images of $\mathrm{MoSe}_{2}$ nanoparticles; (B) TEM images of the MoSe 2 /rGO composite; and (C) XRD spectrum of the rGO, MoSe 2 and $\mathrm{MoSe}_{2} / \mathrm{rGO}$ composite.

\subsection{Enhanced Electrochemical Properties of $\mathrm{MoSe}_{2} / \mathrm{rGO} / \mathrm{GCE}$}

Cyclic voltammogram (CV) were employed to study the electrochemical properties of the bare GCE and modified electrode (Figure S1) in $5 \mathrm{mM} \mathrm{K}_{3}\left[\mathrm{Fe}(\mathrm{CN})_{6}\right]^{3-/ 4-}$ solution (containing $0.1 \mathrm{M} \mathrm{KCl}$ ). The electrochemical response of the ferricyanide probe was a reversible process. At a scan rate of $100 \mathrm{mV} / \mathrm{s}$, the pairs of redox peak currents of bare GCE, rGO/GCE and $\mathrm{MoSe}_{2} / \mathrm{rGO} / \mathrm{GCE}$ were $6.3 \mu \mathrm{A}$, 
$15.6 \mu \mathrm{A}$ and $39.7 \mu \mathrm{A}$, respectively. The higher redox current responses of $\mathrm{MoSe}_{2} / \mathrm{rGO} / \mathrm{GCE}$ than the bare GCE and rGO/GCE could be attributed to its larger surface area due to the introduction of the hierarchy structures of $\mathrm{MoSe}_{2}$ nanoparticles. The better electron transfer resulting from rGO also led to the smaller peak-to-peak potential separation ( $\triangle \mathrm{Ep}$ ) value of the $\mathrm{MoSe}_{2} / \mathrm{rGO} / \mathrm{GCE}(0.089 \mathrm{~V})$.

PTA is proposed as a recommend substance for improving the sensitivity, stability and repeatability of the electrodes [30]. Here, its contribution to the oxidation peak of BPA has also been evaluated. In the detection system, the electrolyte was composed of $1 \mathrm{~mL}$ PTA $(0.1 \mathrm{mM}), 1 \mathrm{~mL}$ BPA $(0.01 \mathrm{mM}), 1 \mathrm{~mL}$ PBS $(1 \mathrm{M}, \mathrm{pH}=6.5)$ and $7 \mathrm{~mL} \mathrm{H}_{2} \mathrm{O}$. Such a low level of PTA had no effect on the $\mathrm{pH}$ value of the electrolyte adjusted by PBS. In the absence of PTA, the cyclic voltammetric was carried out in the potential range of $-0.2 \mathrm{~V}-0.8 \mathrm{~V}$ using GCE as the working electrode. A single smaller oxidation peak $(2.9 \mu \mathrm{A})$ appeared at about $0.6 \mathrm{~V}$ in the beginning due to the oxidation potential of the irreversible phenolic hydroxyl of BPA (Figure 2A) [31], and it disappeared completely after the fourth run. The reversible redox peaks around 0-0.2 V (Figure 2B), which did not interfere with determination peak of BPA, were due to the conversion between hydroxyl and carboxyl groups on the graphene [32]. The attenuated oxidation currents of BPA at around $0.6 \mathrm{~V}$ were observed for $\mathrm{rGO} / \mathrm{GCE}$ after several runs, though the oxidation current was much higher $(16.8 \mu \mathrm{A})$ at the first scan (Figure 2B). The attenuated signals can be largely attributed to the serious surface deactivation of the electrodes for BPA. In the presence of PTA $(0.1 \mathrm{mM})$, the CV signals of both rGO/GCE (Figure 2C) and $\mathrm{MoSe}_{2} / \mathrm{rGO} / \mathrm{GCE}$ (Figure 2D) presented much better stability. After the fifth run, the oxidation currents still reached up to $88 \%(\mathrm{RSD}=5.48 \%, n=5)$ and $98.7 \%(\mathrm{RSD}=0.43 \%, n=5)$ of the initial peak current for $\mathrm{rGO} / \mathrm{GCE}$ and $\mathrm{MoSe}_{2} / \mathrm{rGO} / \mathrm{GCE}$, respectively. The enhancement of the stability of the oxidation signals of BPA should be attributed to the anti-fouling capacity of PTA, which can oxidize the phenoxyl radical to the carbocation [32]. Additionally, the better stability $(\operatorname{RSD}=0.43 \%, n=5)$ and sensitivity $(26.5 \mu \mathrm{A})$ of $\mathrm{MoSe}_{2} / \mathrm{rGO} / \mathrm{GCE}$ compared to $\mathrm{rGO} / \mathrm{GCE}$ could be ascribed to the larger surface of $\mathrm{MoSe}_{2}$ nanoparticles, which can increase the active sites and facilitate the electron exchange.
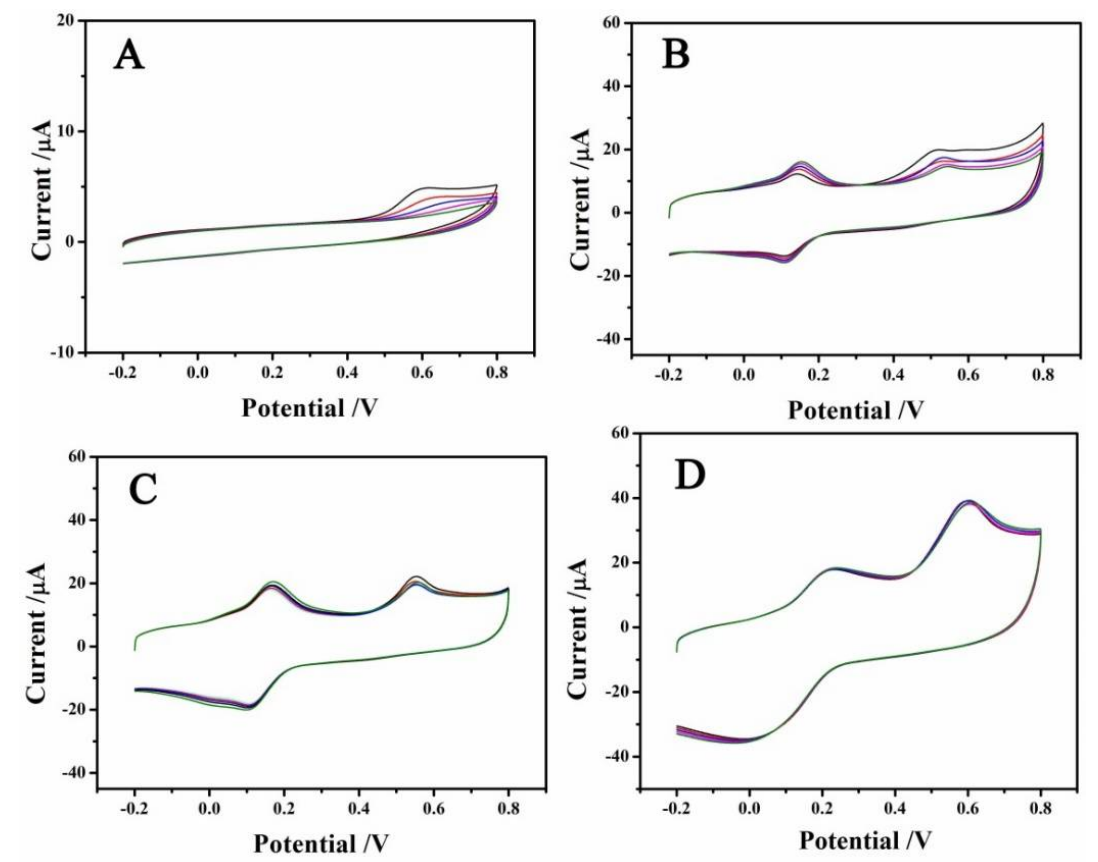

Figure 2. CVs of different electrodes for detecting BPA (0.01 $\mathrm{mM}$ in PBS solution, $\mathrm{pH}=6.5)$ at a scan rate of $100 \mathrm{mV} / \mathrm{s}$. (A) bare GCE; (B) rGO/GCE in the absence of phosphotungstic acid (PTA); (C) $\mathrm{rGO} / \mathrm{GCE}$ in the presence of PTA; (D) $\mathrm{MoSe}_{2} / \mathrm{rGO} / \mathrm{GCE}$ in the presence of PTA. 


\subsection{Reaction Mechanism of BPA on the Surface of $\mathrm{MoSe}_{2} / r G O / G C E$}

It has been reported that the reaction of BPA on the surface of $\mathrm{MoSe}_{2} / \mathrm{rGO} / \mathrm{GCE}$ is proton-dependent $(0.1 \mathrm{mM})$, and the oxidation potential would change with $\mathrm{pH}$ variations of the electrolyte [22]. As shown in Figure 3, the highest oxidation current toward the oxidation of BPA on the surface of $\mathrm{MoSe}_{2} / \mathrm{rGO} / \mathrm{GCE}$ appeared at a $\mathrm{pH}$ of 6.5. Additionally, the oxidation potentials $\left(E_{p a}\right)$ of BPA were inversely associated with the $\mathrm{pH}$ values (Figure 3B). The regression equation could be expressed as $E_{p a}(\mathrm{~V})=-0.0554 \mathrm{pH}+0.9641\left(R^{2}=0.994\right)$. The slope of $0.0554 \mathrm{~V} / \mathrm{pH}$ was close to the theoretical value of $0.0576 \mathrm{~V} / \mathrm{pH}$ [22], indicating that the electron transfer was accompanied by an equal number of proton consumption in the electrode reaction of BPA.
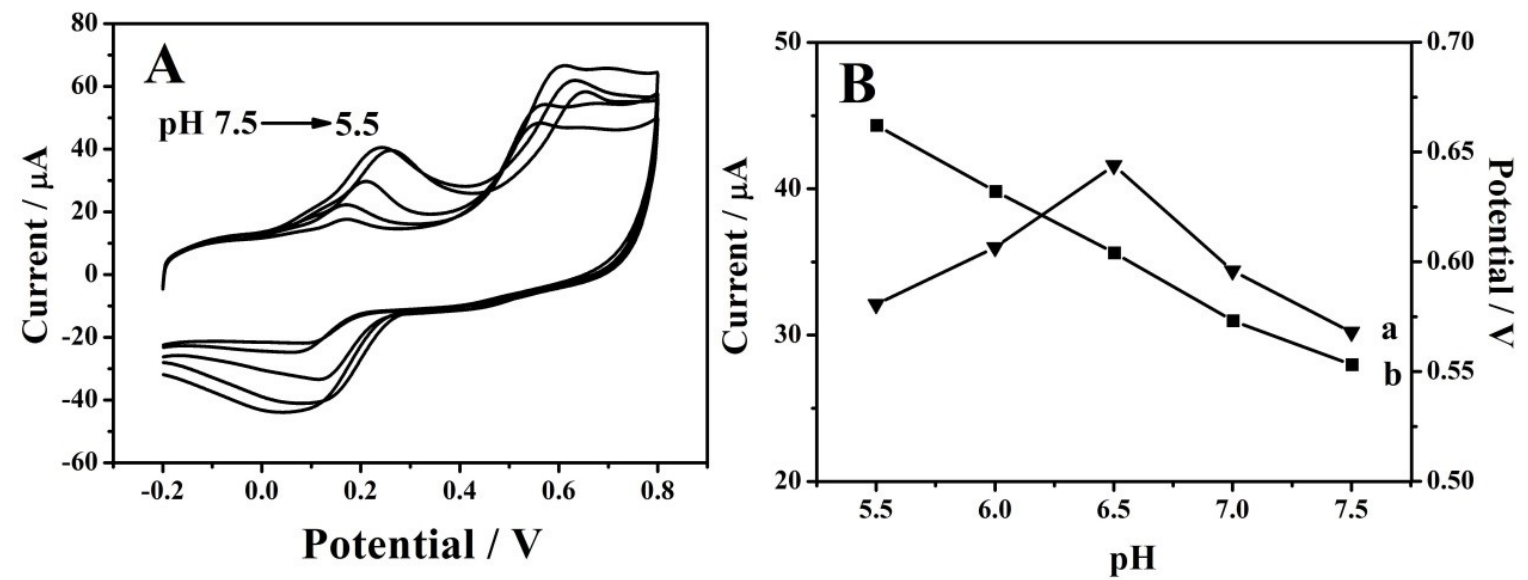

Figure 3. (A) CVs of BPA $(0.1 \mu \mathrm{M})$ using $\mathrm{MoSe}_{2} / \mathrm{rGO} / \mathrm{GCE}$ with different $\mathrm{pHs}$ (from 5.5-7.5); (B) variation of peak current (a) and peak potential (b) with different $\mathrm{pHs}$. The scan rate was $100 \mathrm{mV} / \mathrm{s}$, and the electrolyte was $0.1 \mathrm{M}$ PBS.

The relationship of currents and the scan rate was investigated to understand the reaction kinetics of BPA on the surface of $\mathrm{MoSe}_{2} / \mathrm{rGO} / \mathrm{GCE}$. The peak currents $\left(I_{p a}\right)$ increased linearly with the scan rates $(v)$ in the range of $10-300 \mathrm{mV} / \mathrm{s}$ (Figure $4 \mathrm{~A}$ ), indicating that the reaction should be an adsorption-controlled process (Figure 4B) [33]. Additionally, there is a linear relationship between the oxidation peak potential $\left(E_{p a}\right)$ and the nature logarithmic scan rate (lnv) (Figure $4 \mathrm{~B}$ ). The relationship can be expressed using the following regression equation: $E_{p a}(\mathrm{~V})=0.0229 \ln v+0.4594\left(R^{2}=0.995\right)$. According to the Laviron equation, $E_{p a}$ of an irreversible electrode process can be defined by the following equation:

$$
E p a=E^{0}+\left(\frac{R T}{\alpha n F}\right) \operatorname{In}\left(\frac{R T \kappa^{0}}{\alpha n F}\right)+\left(\frac{R T}{\alpha n F}\right) \operatorname{In} v
$$

where $\alpha$ is the transfer coefficient, $k^{0}$ is the rate constant of the electrochemical reaction, $n$ is the number of electrons transferred, $v$ is the scan rate and $E^{0}$ is the formal potential. Other symbols have their usual meanings $\left(R=8.314 \mathrm{~J} \mathrm{~mol}^{-1} \mathrm{~K}^{-1}, T=298 \mathrm{~K}, F=96,480 \mathrm{C} \mathrm{mol}^{-1}\right)$. Based on the slope of 0.0229 , the calculated $\alpha n(\alpha=0.5)$ was 1.1213, indicating that the electron transfer number $(n)$ for BPA oxidation was around two. 

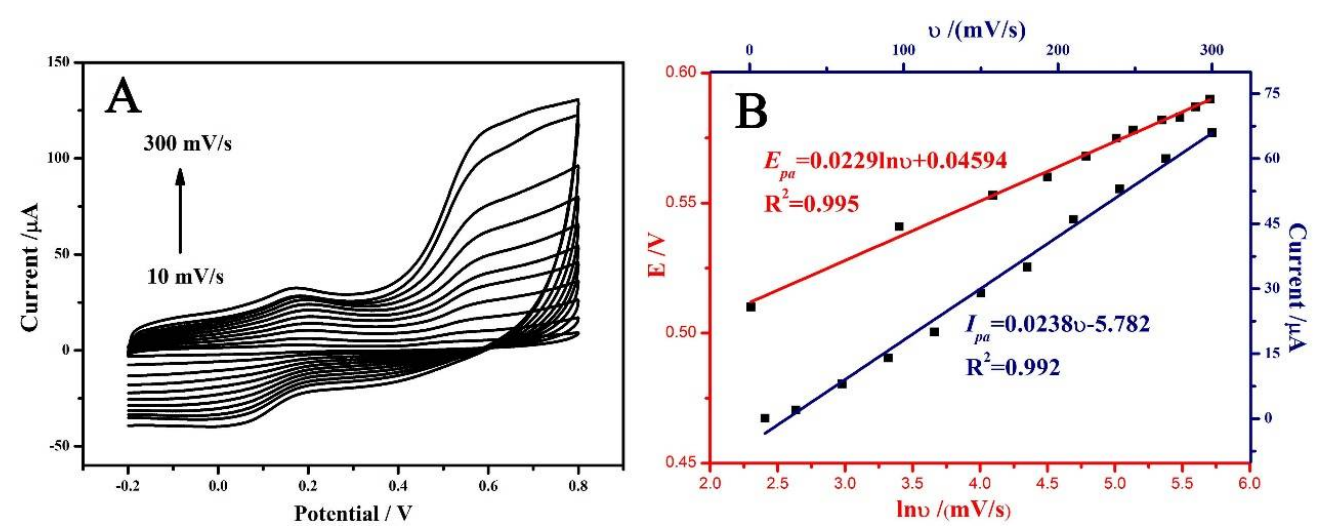

Figure 4. (A) CVs of BPA at $\mathrm{MoSe}_{2} / \mathrm{rGO} / \mathrm{GCE}$ in $0.1 \mathrm{M}$ PBS $(\mathrm{pH}=6.5)$ at different scan rates; (B) the relationship of peak currents $\left(I_{p a}\right)$ with the scan rates $(v)$ and peak potentials $\left(E_{p a}\right)$ with the scan rates.

\subsection{Interference Analysis}

Under the optimum conditions ( $\mathrm{pH}$ 6.5), the influence of the coexisting ions and BPA analogs for determining BPA $(10.0 \mu \mathrm{M})$ by $\mathrm{MoSe}_{2} / \mathrm{rGO} / \mathrm{GCE}$ has been tested, and the results are shown in Table S1. The inorganic substances of $\mathrm{KCl}, \mathrm{NaCl}, \mathrm{CaCl}_{2}, \mathrm{BaCl}_{2}, \mathrm{CuCl}_{2}, \mathrm{FeCl}_{3}$ and $\mathrm{NaOH}(1 \mathrm{mM})$ presented little effect, with the peak current suppression or enhancement less than $2.71 \%$. More interestingly, it was also found that there was no obvious effect on the peak current variations of BPA oxidation when the concentration was 10-times BPA for its analogs of phenol, bisphenol S, bisphenol F and bisphenol B. The results suggested that the $\mathrm{MoSe}_{2} / \mathrm{rGO} / \mathrm{GCE}$ possesses good selectivity and anti-interference ability towards BPA oxidation.

\subsection{Analytical Performance}

Under the optimized conditions, CVs of BPA with different concentrations were recorded. As expected, the anodic peak current of BPA $\left(I_{p a}\right)$ at $\mathrm{MoSe}_{2}-\mathrm{rGO} / \mathrm{GCE}$ gradually increased, accompanied by BPA levels increasing. The $I_{p a}$ of the BPA was the average value determined by five measurements. As no anodic peak appeared in the absence of BPA, no baseline correction was performed in our experiment. Ultimately, a linear regression equation $I_{p a}(\mu \mathrm{A})=0.78 \mathrm{C}(\mu \mathrm{M})+36.64$ $\left(R^{2}=0.988\right)$ was obtained when BPA concentrations ranged from $0.1 \mu \mathrm{M}$ to $100 \mu \mathrm{M}$ (Figure 5). The detection limit (DL) $(\mathrm{S} / N=3)$ was $0.015 \mu \mathrm{M}$. Compared with other modified electrodes for BPA analysis detection limits (DLs $>0.04 \mu \mathrm{M}$ ) [34-38], the $\mathrm{MoSe}_{2} / \mathrm{rGO} / \mathrm{GCE}$ electrode presented comparable or even better sensitivity, except for the $\mathrm{Ni}_{2}$ Al-layered double hydroxide/GCE electrode [39] and the AuNPs/ $\mathrm{MoSe}_{2}$ /GCE electrode [40].
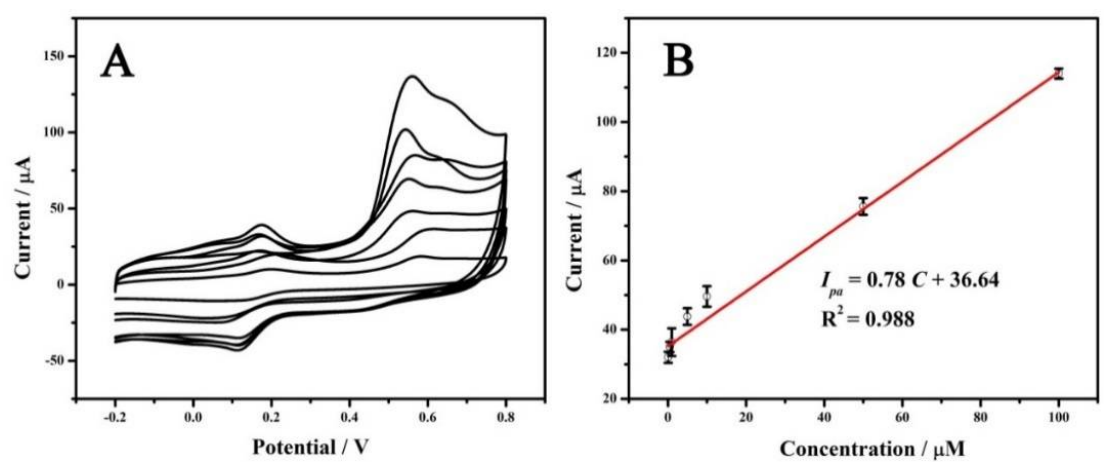

Figure 5. (A) CVs of $\mathrm{MoSe}_{2} / \mathrm{rGO} / \mathrm{GCE}$ in $1 \mathrm{M}$ PBS (pH 6.5) containing different concentrations of BPA (from the bottom to top: $0.1,0.5,1,5,10,50,100 \mu \mathrm{M}$ ); (B) the calibration line of the response $I_{p a}$ vs. $\mathrm{C}_{\mathrm{BPA}}$. 
$\mathrm{MoSe}_{2} / \mathrm{rGO} / \mathrm{GCE}$ also presented good stability, repeatability and reproducibility when analyzing dissolved BPA. After storing in refrigerator at $4{ }^{\circ} \mathrm{C}$ for two weeks, the response of $\mathrm{MoSe}_{2} / \mathrm{rGO} / \mathrm{GCE}$ only reduced by less than $10 \%$. The RSD of the response signals of individual $\mathrm{MoSe}_{2} / \mathrm{rGO} / \mathrm{GCE}$ towards BPA oxidation $(0.43 \%, n=5)$ was much lower than some modified electrodes (Table 1$)$. RSD obtained from three parallel prepared $\mathrm{MoSe}_{2} / \mathrm{rGO} / \mathrm{GCE}$ was only $2.2 \%$, still at a lower level for those modified electrodes determining BPA (Table 1).

Table 1. Comparison of the $\mathrm{MoSe}_{2} / \mathrm{rGO}$ modified electrode for BPA determination with other modified electrodes $\left(\mathrm{C}_{\mathrm{BPA}}=100 \mu \mathrm{M}\right)$.

\begin{tabular}{|c|c|c|c|c|c|c|}
\hline Modified Electrode & $\begin{array}{c}\text { Linear Range } \\
(\mu \mathrm{M})\end{array}$ & $\begin{array}{c}\text { Detection } \\
\text { Limit }(\mu \mathrm{M})\end{array}$ & $\begin{array}{l}\text { Repeatability } \\
\text { (RSD) }\end{array}$ & $\begin{array}{l}\text { Reproducibility } \\
\text { (RSD) }\end{array}$ & Medium & Reference \\
\hline $\begin{array}{l}\text { Magnetic non-imprinted } \\
\text { NPs/CPE }\end{array}$ & $0.6-100$ & 0.1 & $n=7,1.4 \%$ & $4.3 \%$ & water & [34] \\
\hline $\begin{array}{l}\text { polypyrrole/graphene } \\
\text { quantum dots/GCE }\end{array}$ & $0.1-50$ & 0.04 & $2.2 \%$ & - & water & [23] \\
\hline $\mathrm{AuNPs} / \mathrm{MoS}_{2} / \mathrm{GCE}$ & $0.05-100$ & 0.005 & $n=10,2.35 \%$ & $4.72 \%$ & rubber, water & [40] \\
\hline $\mathrm{Pt}$ /graphene-CNTs & $0.06-10,10-80$ & 0.042 & $n=5,5.3 \%$ & - & $\begin{array}{l}\text { thermal printing } \\
\text { papers }\end{array}$ & {$[36]$} \\
\hline $\begin{array}{c}\text { AuNPs/tacked graphene } \\
\text { nanofibers/GCE }\end{array}$ & $0.08-250$ & 0.035 & $n=10,2.55 \%$ & $4.46 \%$ & bottles & [37] \\
\hline $\mathrm{MoSe}_{2} / \mathrm{rGO}$ & $0.1-100$ & 0.012 & $n=5,0.429 \%$ & $2.2 \%$ & beverages & This work \\
\hline
\end{tabular}

\subsection{Samples Analysis}

Before adding BPA into the solutions containing liquid milk, orange juice, coffee, soybean milk and prepared juice, BPA in almost all these solutions was below the detection limit except that in the orange juice with a detectable BPA concentration of $1.7 \mu \mathrm{M}$ (Table 2). The detected BPA was further identified and quantified by using HPLC-LTQ-MS (Figure S2). Based on the identification of the standards, BPA was observed at a retention time of $7.8 \mathrm{~min}$ with the specific ions at $\mathrm{m} / \mathrm{z}$ of $227\left([\mathrm{M}-\mathrm{H}]^{-}\right), 211.9\left(\left[\mathrm{M}-\mathrm{H}-\mathrm{CH}_{3}\right]^{-}\right)$and $182.9\left(\left[\mathrm{M}-\mathrm{H}-\mathrm{C}_{2} \mathrm{H}_{4} \mathrm{O}\right]^{-}\right)[41]$, and its concentration was about $1.8 \mu \mathrm{M}$. After spiking at three levels $(10,15$ and $20 \mu \mathrm{M})$, BPA could be detected in all the solutions (Table 2). The recoveries ranged from $98 \%$ to $107 \%$, and the calculated RSDs were all lower than 3\%. These results indicated that the $\mathrm{MoSe}_{2} / \mathrm{rGO} / \mathrm{GCE}$ sensor could be a potential strategy for routine analysis of BPA, especially in some liquid samples [41].

Table 2. Determination results of BPA in real samples.

\begin{tabular}{ccccc}
\hline Sample & Added $(\boldsymbol{\mu M})$ & Found $(\boldsymbol{\mu M}, \boldsymbol{n = 5 )}$ & RSD $(\%, \boldsymbol{n = 5 )}$ & Recovery (\%) \\
\hline \multirow{2}{*}{ Liquid milk } & 0 & $<$ LOD & & \\
& 10 & $10.08 \pm 0.243$ & 2.40 & 100.8 \\
& 15 & $15.09 \pm 0.067$ & 0.45 & 100.6 \\
Orange juice & 20 & $20.69 \pm 0.361$ & 1.18 & 103.5 \\
\hline & 10 & 1.7 & & 101.6 \\
& 15 & $10.16 \pm 0.102$ & 1.00 & 104.4 \\
\hline
\end{tabular}


Table 2. Cont.

\begin{tabular}{ccccc}
\hline Sample & Added $(\boldsymbol{\mu M})$ & Found $(\boldsymbol{\mu M}, \boldsymbol{n = 5 )}$ & RSD (\%, $\boldsymbol{n = 5 )}$ & Recovery (\%) \\
\hline \multirow{2}{*}{ Coffee } & 0 & $<$ LOD & & \\
& 10 & $10.30 \pm 0.282$ & 2.75 & 103.0 \\
& 15 & $15.21 \pm 0.212$ & 1.39 & 101.4 \\
Soybean milk & 20 & $20.98 \pm 0.552$ & 2.62 & 104.9 \\
\hline \multirow{3}{*}{ Prepared juice } & 10 & $<$ LOD & & 98.8 \\
& 15 & $9.88 \pm 0.145$ & 1.47 & 102.7 \\
& 20 & $20.47 \pm 0.250$ & 1.68 & 102.4 \\
\hline
\end{tabular}

\section{Conclusions}

In summary, a simple electrochemical sensor based on $\mathrm{MoSe}_{2} / \mathrm{rGO}$-modified GCE has been successfully fabricated for in situ determination of BPA in aqueous samples. Combined with the good conductivity of rGO and the positive catalysis of $\mathrm{MoSe}_{2}$, the $\mathrm{MoSe}_{2} / \mathrm{rGO}$ composites provided a favorable sensitivity for analyzing BPA. The prepared $\mathrm{MoSe}_{2} / \mathrm{rGO} / \mathrm{GCE}$ sensor displayed a wide linear range, low detection limit, good stability, repeatability, reproducibility and high recoveries. The good performance for in situ determination of BPA in real samples indicated that the $\mathrm{MoSe}_{2} / \mathrm{rGO} / \mathrm{GCE}$ sensor could be a potential strategy for routine analysis of BPA.

Supplementary Materials: The following are available online at http:/ /www.mdpi.com/1424-8220/18/5/1660/ s1, Table S1: Analytical results of BPA in the presence of interfering substances, Figure S1: CVs of (a) bare electrode, (b) $\mathrm{rGO} / \mathrm{GCE}$ and (c) $\mathrm{MoSe}_{2} / \mathrm{rGO} / \mathrm{GCE}$ in $5 \mathrm{mM}[\mathrm{Fe}(\mathrm{CN}) 6]^{3-/ 4-}$ containing $0.1 \mathrm{M} \mathrm{KCl}$ at a scan rate of $100 \mathrm{mV} / \mathrm{s}$, Figure S2: Confirmation of bisphenol A in orange juice by HPLC-LTQ-MS.

Author Contributions: Conceptualization, Z.Z., Y.L. and R.S.; Methodology, J.L.; Software, J.L.; Validation, A.L., J.L. and Z.Z.; Writing-Original Draft Preparation, R.S.; Writing-Review \& Editing, Z.Z., Y.L. and A.L.; Funding Acquisition, Y.L. and A.L.

Funding: This work was supported by the National Natural Science Foundation of China (Grant Numbers 21607161, 21402192) and the Open Fund of the Key Laboratory for Environmental Factors Control of Agro-product Quality Safety, Ministry of Agriculture.

Conflicts of Interest: The authors declare no conflicts of interest.

\section{References}

1. Rosenfeld, C.S. Bisphenol A and phthalate endocrine disruption of parental and social behaviors. Front. Neurosci. 2015, 9, 57. [CrossRef] [PubMed]

2. Ji, Y.; Yin, J.; Xu, Z.; Zhao, C.; Huang, H.; Zhang, H.; Wang, C. Preparation of magnetic molecularly imprinted polymer for rapid determination of bisphenol A in environmental water and milk samples. Anal. Bioanal. Chem. 2009, 395, 1125-1133. [CrossRef] [PubMed]

3. Khedr, A. Optimized extraction method for LC-MS determination of bisphenol A, melamine and di(2-ethylhexyl) phthalate in selected soft drinks, syringes, and milk powder. J. Chromatogr. B 2013, 930, 98-103. [CrossRef] [PubMed]

4. Deng, P.; Xu, Z.; Kuang, Y. Electrochemical determination of bisphenol A in plastic bottled drinking water and canned beverages using a molecularly imprinted chitosan-graphene composite film modified electrode. Food Chem. 2014, 157, 490-497. [CrossRef] [PubMed]

5. Calafat, A.M.; Ye, X.; Wong, L.-Y.; Reidy, J.A.; Needham, L.L. Exposure of the U.S. Population to bisphenol A and 4-tertiary-octylphenol: 2003-2004. Environ. Health Perspect. 2008, 116, 39-44. [CrossRef] [PubMed]

6. Howdeshell, K.L.; Hotchkiss, A.K.; Thayer, K.A.; Vandenbergh, J.G.; vom Saal, F.S. Environmental toxins: Exposure to bisphenol A advances puberty. Nature 1999, 401, 763-764. [PubMed] 
7. Lang, I.A.; Galloway, T.S.; Scarlett, A.; Henley, W.E.; Depledge, M.; Wallace, R.B.; Melzer, D. Association of urinary bisphenol A concentration with medical disorders and laboratory abnormalities in adults. JAMA 2008, 300, 1303-1310. [CrossRef] [PubMed]

8. Mirmira, P.; Evans-Molina, C. Bisphenol A, obesity, and type 2 diabetes mellitus: Genuine concern or unnecessary preoccupation? Transl. Res. 2014, 164, 13-21. [CrossRef] [PubMed]

9. Bacle, A.; Thevenot, S.; Grignon, C.; Belmouaz, M.; Bauwens, M.; Teychene, B.; Venisse, N.; Migeot, V.; Dupuis, A. Determination of bisphenol A in water and the medical devices used in hemodialysis treatment. Int. J. Pharm. 2016, 505, 115-121. [CrossRef] [PubMed]

10. Pouokam, G.B.; Ajaezi, G.C.; Mantovani, A.; Orisakwe, O.E.; Frazzoli, C. Use of bisphenol A-containing baby bottles in cameroon and nigeria and possible risk management and mitigation measures: Community as milestone for prevention. Sci. Total Environ. 2014, 481, 296-302. [CrossRef] [PubMed]

11. Zhang, X.; Zhu, D.; Huang, C.; Sun, Y.; Lee, Y.-I. Sensitive detection of bisphenol A in complex samples by in-column molecularly imprinted solid-phase extraction coupled with capillary electrophoresis. Microchem. J. 2015, 121, 1-5. [CrossRef]

12. Li, D.; Park, J.; Oh, J.R. Silyl derivatization of alkylphenols, chlorophenols, and bisphenol A for simultaneous GC/MS determination. Anal. Chem. 2001, 73, 3089-3095. [CrossRef] [PubMed]

13. Alexiadou, D.K.; Maragou, N.C.; Thomaidis, N.S.; Theodoridis, G.A.; Koupparis, M.A. Molecularly imprinted polymers for bisphenol A for HPLC and SPE from water and milk. J. Sep. Sci. 2008, 31, 2272-2282. [CrossRef] [PubMed]

14. Huang, C.H.; Sedlak, D.L. Analysis of estrogenic hormones in municipal wastewater effluent and surface water using enzyme-linked immunosorbent assay and gas chromatography/tandem mass spectrometry. Environ. Toxicol. Chem. 2001, 20, 133-139. [CrossRef] [PubMed]

15. Kazane, I.; Gorgy, K.; Gondran, C.; Spinelli, N.; Zazoua, A.; Defrancq, E.; Cosnier, S. Highly sensitive bisphenol-A electrochemical aptasensor based on poly(pyrrole-nitrilotriacetic acid)-aptamer. Anal. Chem. 2016, 88, 7268-7273. [CrossRef] [PubMed]

16. Wannapob, R.; Thavarungkul, P.; Dawan, S.; Numnuam, A.; Limbut, W.; Kanatharana, P. A simple and highly stable porous gold-based electrochemical sensor for bisphenol A detection. Electroanalysis 2017, 29, 472-480. [CrossRef]

17. Li, X.; Chu, S.; Fu, S.; Ma, L.; Liu, X.; Xu, X. Off-line concentration of bisphenol A and three alkylphenols by SPE then on-line concentration and rapid separation by reverse-migration micellar electrokinetic chromatography. Chromatographia 2005, 61, 161-166. [CrossRef]

18. Vilchez, J.L.; Zafra, A.; Gonzalez-Casado, A.; Hontorio, E.; del Olmo, M. Determination of trace amounts of bisphenol $\mathrm{f}$, bisphenol A and their diglycidyl ethers in wastewater by gas chromatography-mass spectrometry. Anal. Chim. Acta 2001, 431, 31-40. [CrossRef]

19. Sungur, S.; Koroglu, M.; Ozkan, A. Determination of bisphenol A migrating from canned food and beverages in markets. Food Chem. 2014, 142, 87-91. [CrossRef] [PubMed]

20. Yan, W.; Li, Y.; Zhao, L.; Lin, J.-M. Determination of estrogens and bisphenol A in bovine milk by automated on-line C30 solid-phase extraction coupled with high-performance liquid chromatography-mass spectrometry. J. Chromatogr. A 2009, 1216, 7539-7545. [CrossRef] [PubMed]

21. Liu, M.; Hashi, Y.; Pan, F.; Yao, J.; Song, G.; Lin, J.-M. Automated on-line liquid chromatography-photodiode array-mass spectrometry method with dilution line for the determination of bisphenol A and 4-octylphenol in serum. J. Chromatogr. A 2006, 1133, 142-148. [CrossRef] [PubMed]

22. Messaoud, N.B.; Ghica, M.E.; Dridi, C.; Ali, M.B.; Brett, C.M. Electrochemical sensor based on multiwalled carbon nanotube and gold nanoparticle modified electrode for the sensitive detection of bisphenol A. Sens. Actuators B Chem. 2017, 253, 513-522. [CrossRef]

23. Tan, F.; Cong, L.; Li, X.; Zhao, Q.; Zhao, H.; Quan, X.; Chen, J. An electrochemical sensor based on molecularly imprinted polypyrrole/graphene quantum dots composite for detection of bisphenol A in water samples. Sens. Actuators B Chem. 2016, 233, 599-606. [CrossRef]

24. Dadkhah, S.; Ziaei, E.; Mehdinia, A.; Kayyal, T.B.; Jabbari, A. A glassy carbon electrode modified with amino-functionalized graphene oxide and molecularly imprinted polymer for electrochemical sensing of bisphenol A. Microchim. Acta 2016, 183, 1933-1941. [CrossRef]

25. Liao, Y.; Zhao, Z. Effects of phosphoric acid and ageing time on solvent extraction behavior of phosphotungstic acid. Hydrometallurgy 2017, 169, 515-519. [CrossRef] 
26. Gan, T.; Hu, C.; Chen, Z.; Hu, S. Fabrication and application of a novel plant hormone sensor for the determination of methyl jasmonate based on self-assembling of phosphotungstic acid-graphene oxide nanohybrid on graphite electrode. Sens. Actuators B Chem. 2010, 151, 8-14. [CrossRef]

27. Xia, X.; Shen, X.; Du, Y.; Ye, W.; Wang, C. Study on glutathione's inhibition to dopamine polymerization and its application in dopamine determination in alkaline environment based on silver selenide/molybdenum selenide/glassy carbon electrode. Sens. Actuators B Chem. 2016, 237, 685-692. [CrossRef]

28. Huang, K.-J.; Zhang, J.-Z.; Cai, J.-L. Preparation of porous layered molybdenum selenide-graphene composites on $\mathrm{Ni}$ foam for high-performance supercapacitor and electrochemical sensing. Electrochim. Acta 2015, 180, 770-777. [CrossRef]

29. Shi, R.; Liang, J.; Zhao, Z.; Liu, A.; Tian, Y. An electrochemical bisphenol A sensor based on one step electrochemical reduction of cuprous oxide wrapped graphene oxide nanoparticles modified electrode. Talanta 2017, 169, 37-43. [CrossRef] [PubMed]

30. Zhao, W.; Kang, T.; Lu, L.; Shen, F.; Cheng, S. A novel electrochemical sensor based on gold nanoparticles and molecularly imprinted polymer with binary functional monomers for sensitive detection of bisphenol A. J. Electroanal. Chem. 2017, 786, 102-111. [CrossRef]

31. Toh, S.Y.; Loh, K.S.; Kamarudin, S.K.; Daud, W.R.W. Graphene production via electrochemical reduction of graphene oxide: Synthesis and characterisation. Chem. Eng. J. 2014, 251, 422-434. [CrossRef]

32. Hossain, M.M.; Aldous, L. Polyoxometalates as solution-phase electrocatalytic mediators for reduced electrode fouling and the improved oxidative response of phenols. Electrochem. Commun. 2016, 69, 32-35. [CrossRef]

33. Najafi, M.; Khalilzadeh, M.A.; Karimi-Maleh, H. A new strategy for determination of bisphenol A in the presence of Sudan I using a ZNO/CNTs/ionic liquid paste electrode in food samples. Food Chem. 2014, 158, 125-131. [CrossRef] [PubMed]

34. Zhu, L.; Cao, Y.; Cao, G. Electrochemical sensor based on magnetic molecularly imprinted nanoparticles at surfactant modified magnetic electrode for determination of bisphenol A. Biosens. Bioelectron. 2014, 54, 258-261. [CrossRef] [PubMed]

35. Yu, X.; Chen, Y.; Chang, L.; Zhou, L.; Tang, F.; Wu, X. B-cyclodextrin non-covalently modified ionic liquid-based carbon paste electrode as a novel voltammetric sensor for specific detection of bisphenol A. Sens. Actuators B Chem. 2013, 186, 648-656. [CrossRef]

36. Zheng, Z.; Du, Y.; Wang, Z.; Feng, Q.; Wang, C. Pt/graphene-CNTs nanocomposite based electrochemical sensors for the determination of endocrine disruptor bisphenol A in thermal printing papers. Analyst 2013, 138, 693-701. [CrossRef] [PubMed]

37. Niu, X.; Yang, W.; Wang, G.; Ren, J.; Guo, H.; Gao, J. A novel electrochemical sensor of bisphenol A based on stacked graphene nanofibers/gold nanoparticles composite modified glassy carbon electrode. Electrochim. Acta 2013, 98, 167-175. [CrossRef]

38. Cosio, M.S.; Pellicanò, A.; Brunetti, B.; Fuenmayor, C.A. A simple hydroxylated multi-walled carbon nanotubes modified glassy carbon electrode for rapid amperometric detection of bisphenol A. Sens. Actuators $B$ Chem. 2017, 246, 673-679. [CrossRef]

39. Zhan, T.; Song, Y.; Tan, Z.; Hou, W. Electrochemical bisphenol A sensor based on exfoliated Ni ${ }_{2} \mathrm{Al}-$ layered double hydroxide nanosheets modified electrode. Sens. Actuators B Chem. 2017, 238, 962-971. [CrossRef]

40. Huang, K.-J.; Liu, Y.-J.; Liu, Y.-M.; Wang, L.-L. Molybdenum disulfide nanoflower-chitosan-Au nanoparticles composites based electrochemical sensing platform for bisphenol A determination. J. Hazard. Mater. 2014, 276, 207-215. [CrossRef] [PubMed]

41. Gallart-Ayala, H.; Moyano, E.; Galceran, M.T. Liquid chromatography/multi-stage mass spectrometry of bisphenol A and its halogenated derivatives. Rapid Commun. Mass Spectrom. 2007, 21, 4039-4048. [CrossRef] [PubMed]

(C) 2018 by the authors. Licensee MDPI, Basel, Switzerland. This article is an open access article distributed under the terms and conditions of the Creative Commons Attribution (CC BY) license (http:/ / creativecommons.org/licenses/by/4.0/). 